\title{
Electrosynthesis of nitrogen heterocycles using environmentally friendly methodologies
}

\author{
X. Chaminade ${ }^{a}$, E. Duñach ${ }^{a}$, A. P. Esteves ${ }^{b}$, M. J. Medeiros ${ }^{b *}$, C.S. Neves ${ }^{b}$, S. \\ Olivero $^{\mathbf{a}}$ \\ ${ }^{a}$ Laboratoire de Chimie des Molécules Bioactives et des Arômes, CNRS, UMR 6001, Institut de \\ Chimie de Nice, Université de Nice-Sophia Antipolis, Faculté des Sciences, Parc Valrose, 06108 \\ Nice Cedex 2, France \\ ${ }^{b}$ Centro de Química, Universidade do Minho, Largo do Paço, 4704-553 Braga, Portugal
}

\begin{abstract}
Cyclic voltammetry and constant-current electrolysis in a one-compartment cell with a sacrificial anode has been used to study the indirect electroreduction of $N$-allyl- $\alpha$ haloamides by electrogenerated $\mathrm{Ni}(\mathrm{I})$ complexes conducted in $\mathrm{N}, \mathrm{N}$-dimethylformamide $(\mathrm{DMF})$ and acetonitrile $(\mathrm{ACN})$ and the results were compared with those obtained in protic solvents such as EtOH and $\mathrm{EtOH}-\mathrm{H}_{2} \mathrm{O}$ mixtures. It was observed that the indirect electrochemical reduction of $N$-allyl- $\alpha$-haloamides led to the corresponding lactams and the yields and selectivities obtained in $\mathrm{EtOH}$ and $\mathrm{EtOH}-\mathrm{H}_{2} \mathrm{O}$ were much better than those obtained in DMF or ACN.
\end{abstract}

Keywords: ethanol, cyclisation, nickel(II) complexes, electroreduction, heterocycles

\footnotetext{
* Corresponding author: Tel.: +351 253 604050; fax: +351 253678983
} 
E-mail address: medeiros@quimica.uminho.pt (M.J. Medeiros)

\section{Introduction}

Radical cyclisation is a useful method for the synthesis of cyclic compounds. Tributyltin hydride $\left(\mathrm{Bu}_{3} \mathrm{SnH}\right)$ has played an important role as radical reducing reagent despite its neurotocixity and the difficulty of complete removal of tin species from the reaction mixture [1-3]. For example, the construction of lactams by radical cyclisation has attracted much interest, since lactams are important precursors of various alkaloids or amino acid derivatives with potent biological activities [4,5]. A number of useful studies on the construction of lactams by radical cyclisation have been performed and the success of the reaction has been shown to depend strongly on the nature of the substituents on both the $\alpha$-position of the amide and the nitrogen which would affect the stability of both the initially generated radical and the cyclised intermediate [5-9]. On the other hand, substantial efforts have been made to develop a more convenient alternative method and the electrochemical radical-type cyclisations have been successfully used with unsaturated organic halides [10-12], bromoacetals [13], 2-haloaryl ethers [14], bromo propargyloxy esters, bromo allyloxy esters [15-18] and bromopropargyl ethers [19]. These reactions use $\mathrm{Ni}(\mathrm{II})$ complexes as electron-transfer catalysts able to generate $\mathrm{Ni}(\mathrm{I})$ derivatives and the corresponding radicals of the organic halides, which afford the cyclisation products. Ozaki et al. [20,21] have reported that selected nickel(II) complexes catalysed the indirect electroreduction of $\mathrm{N}$-allyl and $\mathrm{N}$-propargyl-a-bromoamides conducted in $\mathrm{N}, \mathrm{N}$ dimethylformamide (DMF) or acetonitrile (ACN) affording the corresponding 5-membered lactams. They also observed that the product distribution was affected by the ability of the solvent to donate hydrogen atom. 
As a part of our investigations into radical cyclisation reactions mediated by $\mathrm{Ni}(\mathrm{II})$ complexes, we report here the electrosynthesis of nitrogen heterocycles from $N$-allyl- $\alpha$ haloamides (1) by using related $\mathrm{Ni}(\mathrm{II})$ complexes as catalysts in DMF and ACN and we compare the results obtained with those in protic solvents such as EtOH and $\mathrm{EtOH}-\mathrm{H}_{2} \mathrm{O}$ mixtures. The use of EtOH as environmentally friendly solvent in reductive intramolecular cyclisations of $N$-allyl- $\alpha$-haloamides has not yet been reported.<smiles>[R]C([X])C(=O)N([R2])CC=C</smiles>

$$
\begin{aligned}
& \text { 1a: } \mathrm{R}_{1}=\mathrm{H} ; \mathrm{R}_{2}=\mathrm{CH}_{3} ; \mathrm{X}=\mathrm{Br} \\
& \text { ․: }: \mathrm{R}_{1}=\mathrm{CH}_{3} ; \mathrm{R}_{2}=\mathrm{CH}_{3} ; \mathrm{X}=\mathrm{Br} \\
& \text { c: } \mathrm{R}_{1}=\mathrm{H} ; \mathrm{R}_{2}=\text { allyl; } \mathrm{X}=\mathrm{Br} \\
& \text { d: }: \mathrm{R}_{1}=\mathrm{CH}_{3} ; \mathrm{R}_{2}=\text { allyl; } \mathrm{X}=\mathrm{Br} \\
& \text { e: }: \mathrm{R}_{1}=\text { phenyl; } \mathrm{R}_{2}=\text { allyl; } \mathrm{X}=\mathrm{Cl}
\end{aligned}
$$

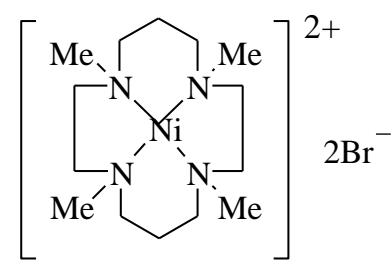

$[\mathrm{Ni}(\mathrm{tmc})] \mathrm{Br}_{2}$

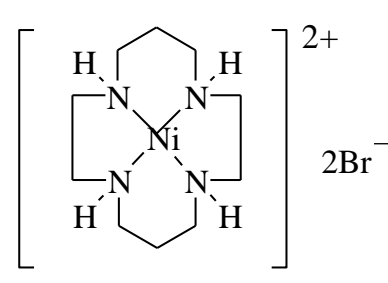

$[\mathrm{Ni}($ cyclam $)] \mathrm{Br}_{2}$

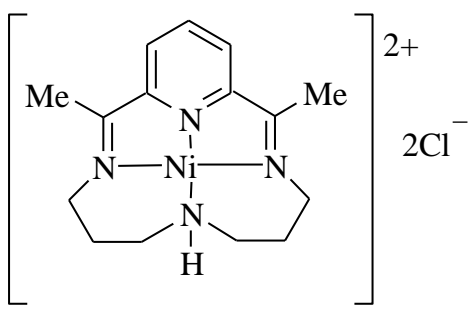

$[\mathrm{Ni}(\mathrm{CR})] \mathrm{Cl}_{2}$

\section{Experimental}

\subsection{Reagents}


Published procedures were employed for the preparation of $[\mathrm{Ni}(\mathrm{tmc})] \mathrm{Br}_{2}$ [22], [Ni(cyclam) $]\left(\mathrm{ClO}_{4}\right)_{2}$ [22], $[\mathrm{Ni}(\mathrm{CR})] \mathrm{Cl}_{2}$ [23] and of $\mathrm{N}$-allyl- $N$-methyl-2-bromoethanamide

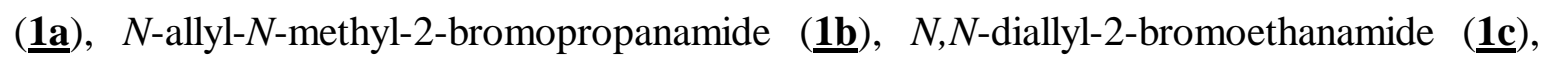

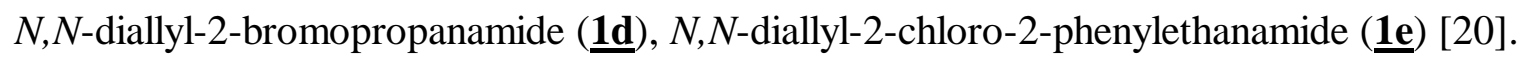

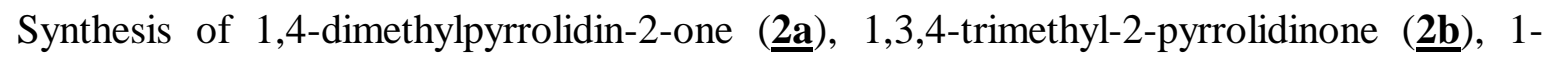

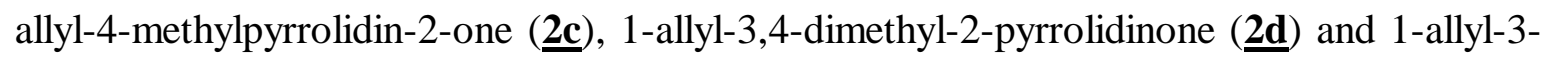
phenyl 4-methyl- 2-pyrrolidinone (르) was based on the method published by McCague et al. [24].

\subsection{Electrodes}

Electrodes for cyclic voltammetry were fabricated from 3-mm-diameter glassy carbon rods (Tokai Electrode Manufacturing Company, Tokyo, Japan, Grade GC-20) press-fitted into Teflon shrouds to provide planar, circular working electrodes with areas of $0.077 \mathrm{~cm}^{2}$. Before use, the electrodes were cleaned with an aqueous suspension of $0.05-\mu \mathrm{m}$ alumina (Buehler) on a Master-Tex (Buehler) polishing pad.

All potentials are quoted with respect to an $\mathrm{Ag} / \mathrm{AgCl} / 3 \mathrm{M} \mathrm{KCl}$ in water reference electrode $(-0.036$ vs SCE).

\subsection{Cells and Instrumentation}

The constant-current electrolyses were carried out in a single-compartment cell (capacity $50 \mathrm{~mL}$ ), such as described in Ref. 25, with a $\mathrm{Zn}$ or $\mathrm{Al}$ or $\mathrm{Mg}$ rod as the sacrificial anode (diameter $1 \mathrm{~cm}$ ) and a carbon fibre cathode (apparent surface, $20 \mathrm{~cm}^{2}$ ) around the counter electrode. Freshly distilled DMF or acetonitrile and ethanol (50 mL), n- $\mathrm{Bu}_{4} \mathrm{NBF}_{4}$ 
or $\mathrm{Et}_{4} \mathrm{NBr}\left(6 \times 10^{-3} \mathrm{M}\right), \mathrm{Ni}^{\mathrm{II}} \mathrm{L}\left(3.0 \times 10^{-3} \mathrm{M}\right)$ and haloamide $\underline{\mathbf{1}}\left(1.5 \times 10^{-2} \mathrm{M}\right)$ were introduced into the cell under argon flow. The solution was stirred and electrolysed at room temperature, at a constant current of $30 \mathrm{~mA}$ (current density of $1.5 \mathrm{~mA} \mathrm{~cm}{ }^{-2}$ and $2-5 \mathrm{~V}$ between the rod anode and the carbon fibre cathode) until disappearance of the starting material (checked by GC analysis of aliquots). Generally, 2-4 F/mol of starting material were necessary to achieve a complete conversion. Controlled-current electrolyses were carried out with the aid of a stabilized constant current supply (Sodilec, EDL 36.07).

Cells for cyclic voltammetry were identical to those described in earlier publications [26]. Cyclic voltammograms were obtained with the aid of an AUTOLAB model PGSTAT12 potentiostat-galvanostat. The data from the above experiments were acquired and stored by locally written software, which controlled a data acquisition board installed in a personal computer.

${ }^{1} \mathrm{H}$ NMR data were recorded on a Bruker 200-MHz Spectrometer in $\mathrm{CDCl}_{3} ; \delta \mathrm{ppm}$ was measured versus residual peak of the solvent. Identities of the electrolysis products were confirmed by means of a Hewlett-Packard 5890 Series II gas chromatograph coupled to a Hewlett-Packard 5971 mass-selective detector and compared to authentic samples.

\subsection{Identification and quantification of products}

After electrolysis, the solvent was evaporated under vacuum, the reaction mixture was

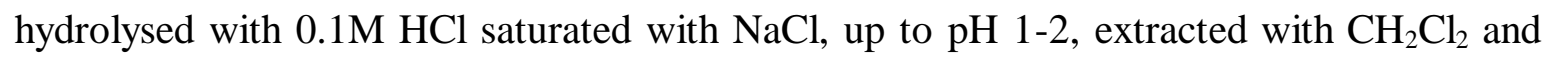
washed with $\mathrm{H}_{2} \mathrm{O}$. The dried $\left(\mathrm{MgSO}_{4}\right)$ organic layer was evaporated and the residue analysed by GC, GC-MS and ${ }^{1} \mathrm{H}-\mathrm{NMR}$, in comparison with those of authentic samples. 
Products were identified by means of ${ }^{1} \mathrm{H}-\mathrm{NMR}$ spectrometry with a Bruker $200-\mathrm{MHz}$ instrument $\left(\mathrm{CDCl}_{3}\right)$ : (a) for $\underline{\mathbf{2 a}}, \delta 3.49(1 \mathrm{H}, \mathrm{dd}, J=9.6$ and $7.8 \mathrm{~Hz}), 2.95(1 \mathrm{H}, \mathrm{dd}, J=9.6$ and $5.7 \mathrm{~Hz}), 2.84(3 \mathrm{H}, \mathrm{s}), 2.60-2.49(1 \mathrm{H}, \mathrm{m}), 2.48-2.37(1 \mathrm{H}, \mathrm{m}), 2.13-1.96(1 \mathrm{H}, \mathrm{m}), 1.13$ $(3 \mathrm{H}, \mathrm{d}, J=6.6 \mathrm{~Hz})$; (b) for $\underline{\mathbf{3 a}}, \delta 5.91-5.70(1 \mathrm{H}, \mathrm{m}), 5.29-5.17(2 \mathrm{H}, \mathrm{m}), 3.99(2 \mathrm{H}, \mathrm{d}, J=$ $5.9 \mathrm{~Hz}), 2.85(\mathrm{~s}, 3 \mathrm{H}), 2.10(3 \mathrm{H}, \mathrm{s})$; (c) for $\underline{\mathbf{3 b}}, \delta 5.80-5.61(\mathrm{~m}, 1 \mathrm{H}) ; 5.17-5.01(\mathrm{~m}, 2 \mathrm{H})$; $3.92(\mathrm{~d}, J=6,7 \mathrm{~Hz} ; 2 \mathrm{H}) ; 2.85(\mathrm{~s}, 3 \mathrm{H}) ; 2.27(\mathrm{q}, J=7.2 \mathrm{~Hz} ; 2 \mathrm{H}) ; 1.10(\mathrm{t}, J=7.2 \mathrm{~Hz} ; 3 \mathrm{H})$; (d) for $\underline{2 c}, \delta 5.77-5.64(1 \mathrm{H}, \mathrm{m}), 5.20-5.18(1 \mathrm{H}, \mathrm{m}), 5.16-5.13(1 \mathrm{H}, \mathrm{m}), 3.86(1 \mathrm{H}$, broad d, $J=6.0 \mathrm{~Hz}), 3.44(1 \mathrm{H}, \mathrm{dd}, J=9.6$ and $7.8 \mathrm{~Hz}), 2.91(1 \mathrm{H}, \mathrm{dd}, J=9.6$ and $5.7 \mathrm{~Hz}), 2.56$ $(1 \mathrm{H}, \mathrm{dd}, J=16.2$ and $8.7 \mathrm{~Hz}), 2.48-2.36(1 \mathrm{H}, \mathrm{m}), 2.03(1 \mathrm{H}, \mathrm{dd}, J=16.2$ and $6.6 \mathrm{~Hz}), 1.11$ $(3 \mathrm{H}, \mathrm{d}, J=6.9 \mathrm{~Hz})$; (e) for $\underline{\mathbf{3 c}}, \delta 5.88-5.68(2 \mathrm{H}, \mathrm{m}), 5.25-5.08(4 \mathrm{H}, \mathrm{m}), 3.99(2 \mathrm{H}, \mathrm{d}, J=$ $5.9 \mathrm{~Hz}), 3.87[2 \mathrm{H}, \mathrm{d}, J=4.4 \mathrm{~Hz}], 2.10(3 \mathrm{H}, \mathrm{s})$; (f) for trans-2d [2 isomers (cis:trans, 78:22)], $\square \delta 5.75-5.55(\mathrm{~m}, J=6.2 \mathrm{~Hz}, 1 \mathrm{H}), 5.13-5.04(\mathrm{~m}, 2 \mathrm{H}), 3.82(\mathrm{~d}, J=6.2 \mathrm{~Hz}, 2 \mathrm{H})$, $3.53(\mathrm{dd}, J=9.8$ and $6.4 \mathrm{~Hz}, 1 \mathrm{H}), 3.28(\mathrm{dd}, J=9.8$ and $7.5 \mathrm{~Hz}, 1 \mathrm{H}), 2.50-2.40(\mathrm{~m}, J=6.3$, 6.4 and $7.5 \mathrm{~Hz}, 1 \mathrm{H}), 2.00-1.75(\mathrm{~m}, J=6.7 \mathrm{~Hz}, 1 \mathrm{H}), 1.11(\mathrm{~d}, J=6.7 \mathrm{~Hz}, 3 \mathrm{H}), 1.05(\mathrm{~d}, J=$ $6.3 \mathrm{~Hz}, 3 \mathrm{H})$; (g) for trans-2e [2 isomers (cis:trans, 20:80)], $\delta$ 7.35-7.09 (m, 5H), 5.83$5.61(\mathrm{~m}, 1 \mathrm{H}), 5.21-5.11(\mathrm{~m}, 2 \mathrm{H}), 4.04-4.01(\mathrm{dd}, J=15.1$ and $6.1 \mathrm{~Hz}, 1 \mathrm{H}), 3.97-3.85(\mathrm{dd}, J$ $=15.1$ and $6.2 \mathrm{~Hz}, 1 \mathrm{H}), 3.50-3.33(\mathrm{~m}, 1 \mathrm{H}), 3.14(\mathrm{~d}, J=9.6 \mathrm{~Hz}, 1 \mathrm{H}), 2.99-2.88(\mathrm{~m}, 1 \mathrm{H})$, 2.41-2.29 (m, $J=9.6$ and $6.9 \mathrm{~Hz}, 1 \mathrm{H}), 1.10(\mathrm{~d}, J=6.9 \mathrm{~Hz}, 3 \mathrm{H})$; and (h) for $\underline{\mathbf{3 e}}, \delta \square 7.38$ $7.10(\mathrm{~m}, 5 \mathrm{H}), 5.83-.5 .52(\mathrm{~m}, 2 \mathrm{H}), 5.25-.4 .95(\mathrm{~m}, 4 \mathrm{H}), 3.93(\mathrm{~d}, J=5.9 \mathrm{~Hz} ; 2 \mathrm{H}), 3,78(\mathrm{~d}, J$ $=4.8 \mathrm{~Hz} ; 2 \mathrm{H}), 3.68(\mathrm{~s}, 2 \mathrm{H})$.

Identities of the products were confirmed with the aid of gas chromatography-mass spectrometry (Hewlett-Packard 5890 Series II gas chromatograph coupled to a HewlettPackard 5971 mass-selective detector): (a) for $\underline{\mathbf{2} a}, m / z(70 \mathrm{eV}) 113\left(\mathrm{M}^{+}, 100\right) ; 98$ (7); 84 (19); 71 (39); (b) for $\underline{\mathbf{3 a}}, \mathrm{m} / z$ (70 eV) $113\left(\mathrm{M}^{+}, 4\right) ; 98$ (18); 70 (100); 56 (29); (c) for $\underline{\mathbf{3} \mathbf{a}}$, 
m/z (70 eV) $115\left(\mathrm{M}^{+}, 43\right) ; 100(44) ; 86(100) ; 72$ (74); (d) for $\underline{\mathbf{2 c}, ~} \mathrm{~m} / z(70 \mathrm{eV}) 139\left(\mathrm{M}^{+}\right.$, 16); 124 (6); 112 (6); 96 (12); 83 (12); 70 (100); 55 (26); (e) for $\underline{\mathbf{2}^{\prime} \mathbf{c}, ~ m / z ~(70 ~ e V) ~} 141\left(\mathrm{M}^{+}\right.$, 20); 126 (8); 112 (100); 98 (4); 84 (63); 67 (7); 55 (43); (f) for $\underline{\mathbf{3 c}, ~ m / z ~(70 ~ e V) ~} 139$ (M+, 2); 124 (2); 111 (2); 98 (18); 82 (18); 70 (41); 56 (100); (g) for $\underline{\mathbf{3}^{\prime} \mathbf{c}, ~} \mathrm{~m} / z(70 \mathrm{eV}) 141\left(\mathrm{M}^{+}\right.$, 3); 126 (6); 112 (4); 98 (5); 84 (4); 70 (100); 56 (16); (h) for ㄹd [two isomers (cis:trans, 78:22)], m/z (70 eV) $153\left(\mathrm{M}^{+}, 100\right) ; 138$ (84); 126 (11); 110 (26); 96 (28); 82 (15); 70

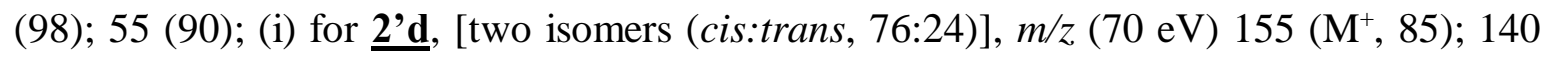

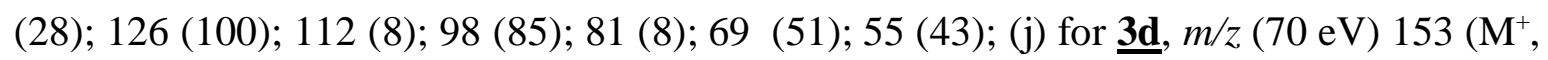
6); 138 (3); 124 (2); 112 (9); 97 (7); 82 (15); 70 (28); 56 (100); (l) for ㄹe , $m / z$ (70 eV) 215 $\left(\mathrm{M}^{+}, 65\right) ; 200$ (14); 131 (17); 117 (100); 91 (57); 70 (29); 56 (10); (m) for 2’e [two isomers (cis:trans, 20:80)], m/z (70 eV) $217\left(\mathrm{M}^{+}, 65\right) ; 202$ (21); 188 (50); 160 (74); 131 (26); 117 (100); 91 (77); 70 (16); 56 (15); (n) for $\underline{\text { 3e, }}$ m/z (70 eV) 215 (M+14); 174 (8); 124 (37); 91 (100); 81 (20); 65 (35); 56 (48); and (o) for $\underline{\text { 3’e, }, ~ m / z ~(70 ~ e V) ~} 219$ (M+, 34); 128 (48); 91 (100); 72 (98); 65 (26); $56(8)$.

\section{Results and discussion}

The electrolyses of amides $\underline{\mathbf{1}}$ were carried out in DMF at constant-current, in a specially designed single-compartment cell, fitted with a consumable sacrificial anode at room temperature, under an inert gas. We first investigated the cyclisation reactions of $N$ allyl- $\alpha$-haloamides $\underline{\mathbf{1 a}}-\underline{\mathbf{1 e}}$ under various conditions in $N, N$-dimethylformamide (DMF) and acetonitrile $(\mathrm{ACN})$ containing $n-\mathrm{Bu}_{4} \mathrm{NBF}_{4}$ as the supporting electrolyte. The results are summarised in Table 1. The study was initiated by carrying out the electrolysis of $\underline{\mathbf{1 a}}$ in $\operatorname{DMF}\left(\right.$ Eq. 1) and in the presence of $[\mathrm{Ni}(\mathrm{tmc})] \mathrm{Br}_{2}$ using a sacrificial magnesium anode and a 
carbon fibre cathode. The expected cyclised product 르 was obtained in $18 \%$ yield along with reduced acyclic products $\underline{\mathbf{3 a}}, \underline{\mathbf{3}^{\prime} \mathbf{a}}$ formed in $22 \%$ (5:95) yield (Table 1, entry 1).<smiles>[R]C(Br)C(=O)N(C)CC=C</smiles>

1a: $\mathrm{R}=\mathrm{H}$ b: $\mathrm{R}=\mathrm{CH}_{3}$<smiles>[R]C1C(=O)N(C)CC1C</smiles>

$\underline{\mathbf{2} \mathbf{a}-\underline{b}}$<smiles>[R]CC(=O)N(C)CC=C</smiles>

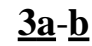<smiles>CCCN(C)C(=O)CC</smiles>

$\underline{\mathbf{3}^{\prime} \mathbf{a}}$

When the same electroreduction was performed in the presence of $30 \mathrm{mM} \mathrm{NH}_{4} \mathrm{ClO}_{4}$ as a H-donor, the cyclized product $\underline{\mathbf{2} \mathbf{a}}$ was produced in $14 \%$ yield together with the reduced acyclic products $\underline{\mathbf{3 a}}, \underline{\mathbf{3} \text { 'a }}$ in $27 \%$ yield (51:49) (Table 1, entry 2). The electroreduction of $\underline{\mathbf{1 b}}$ performed in the presence of $[\mathrm{Ni}($ cyclam $)] \mathrm{Br}_{2}(10 \mathrm{~mol} \%)$ in acetonitrile $(\mathrm{ACN})$ using $\mathrm{Mg} / \mathrm{C}$ electrodes led to the formation of dehalogenated $\underline{\mathbf{3 b}}$ in $78 \%$ yield together with cyclised $\underline{\mathbf{2 b}}$ in $<5 \%$ (Table 1, entry 3 ).

In order to study the influence of the substituents on nitrogen and at the $\alpha$-position of the amide we explored the radical cylisation of compounds $\underline{\mathbf{1 c}}, \underline{\mathbf{1 d}}$ (Eq. 2) and $\underline{\mathbf{1 e}}$ (Eq.3).

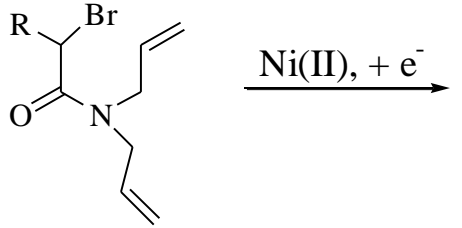

1c: $\mathrm{R}=\mathrm{H}$ d: $\mathrm{R}=\mathrm{CH}_{3}$<smiles>[R]C1C(=O)N(CC=C)CC1C</smiles>

$\underline{\mathbf{2 c}-\underline{\mathbf{d}}}$<smiles>[R]C1C(=O)N(CCC)CC1C</smiles>

$\underline{2} \mathbf{\prime}-\underline{-} \underline{\mathbf{d}}$<smiles>[R]CC(=O)N(CC=C)CC=C</smiles>

$\underline{3 \mathbf{c}}-\underline{\mathbf{d}}$

Thus, the electroreduction of $\underline{\mathbf{1 c}}$ carried out in the presence of $[\mathrm{Ni}(\mathrm{tmc})] \mathrm{Br}_{2}$ using a sacrificial magnesium anode and a carbon fibre cathode resulted in the formation of $\underline{\mathbf{2 c}}, \underline{\mathbf{2}} \mathbf{c}$ 
in $66 \%(79: 21)$ yield, along with formation of $\underline{\mathbf{3 c}}$ in $3 \%$ yield (Table 1, entry 4). The influence of the nature of the anode was next explored and it was observed that the change of anode from magnesium to aluminium led to the formation of $\underline{\mathbf{2}}, \underline{\mathbf{2}}$ 'c in $53 \%$ (94:6) yield, along with formation of $\underline{\mathbf{3 c}}$ in $2 \%$ yield (Table 1 , entry 5 ). It may be concluded that the nature of the anode has a minor effect on product yields. The influence of the nature of the $\mathrm{Ni}(\mathrm{II})$ ligand in the reaction selectivity was also investigated. Thus, the electrolysis of $\underline{\mathbf{1 c}}$ in the presence of $[\mathrm{Ni}(\mathrm{cyclam})] \mathrm{Br}_{2}$ afforded the cyclised product $\underline{\mathbf{2 c}}, \underline{\mathbf{2}} \mathbf{\mathbf { c }}$ in $49 \%$ yield as the major product along with a small amount of $\underline{\mathbf{3 c}}(6 \%)$ (Table 1, entry 6). These results demonstrate that the $[\mathrm{Ni}($ cyclam $)] \mathrm{Br}_{2}$ system efficiently catalyses the cleavage of the carbon-halide bond. The electroreduction of $\underline{\mathbf{1 c}}$ was also performed in the presence of $[\mathrm{Ni}(\mathrm{CR})] \mathrm{Cl}_{2}$ as the catalytic system. Data on products and yields are collected in Table 1 (entry 7) and show that the $[\mathrm{Ni}(\mathrm{CR})] \mathrm{Cl}_{2}$ catalyst inhibits the formation of the cyclised product unlike $[\mathrm{Ni}(\mathrm{tmc})] \mathrm{Br}_{2}$ and $[\mathrm{Ni}($ cyclam $)] \mathrm{Br}_{2}$ systems do. These results indicate that the nature of the ligand on the catalyst has an important effect on the yields and on the selectivity of the reaction products. Using the same procedure, the electroreduction of $\underline{\mathbf{1 d}}$ was studied in the presence of $[\mathrm{Ni}($ cyclam $)] \mathrm{Br}_{2}$ in $\mathrm{ACN}$ leading to the formation of $\underline{\mathbf{2} \mathbf{d}}$ in $27 \%$ and to the reduced acylic compound $\underline{\mathbf{3 d}}$ in $65 \%$ yield (Table 1, entry 8 ).

The same procedure was next applied to the chloroamide $\underline{\mathbf{1 e}}$ in $\mathrm{ACN}$ using $\mathrm{Mg} / \mathrm{C}$ electrodes (Eq. 3).<smiles>C=CCN(CC=C)C(=O)CC(=O)N(CC=C)CC=Cc1ccccc1</smiles> 
Thus, the electrolysis of $\underline{\mathbf{1 e}}$ in the presence of $[\mathrm{Ni}(\mathrm{cyclam})] \mathrm{Br}_{2}$ afforded the cyclised product $\underline{\mathbf{2 e}}$ in $22 \%$ yield together with the dehalogenation product $\underline{\mathbf{3 e}}$ in $55 \%$ yield (Table 1 , entry 9). These results show that the radical cyclisation of haloamides is affected by the nature of the substituent on the nitrogen position and also by the nature of the substituent at the $\alpha$-amide position.

In a perspective aimed at cleaner syntheses, since the $N, N$-dimethylformamide (DMF) or acetonitrile $(\mathrm{ACN})$ as solvents may present some toxicity [27,28], in a previous investigation we have studied the electrochemical radical cylisation of propargyl and allyl bromoalkoxy esters [29] in protic solvents such as ethanol and ethanol-water mixtures. Hence, the cyclisation of $N$-allyl- $\alpha$-haloamides was next examined in EtOH and EtOH$-\mathrm{H}_{2} \mathrm{O}$ mixtures containing $0.006 \mathrm{M} \mathrm{TEABr},[\mathrm{Ni}(\mathrm{tmc})] \mathrm{Br}_{2}$ and $\underline{\mathbf{1}}$. The results are presented in Table 2.

First, the electroreduction of compound $\underline{\mathbf{1 a}}$ was performed in $\mathrm{EtOH}$ using $[\mathrm{Ni}(\mathrm{tmc})] \mathrm{Br}_{2}$ as the catalyst and $\mathrm{Mg} / \mathrm{C}$ electrodes and it was found that the cyclised compound $\underline{\mathbf{2 a}}$ was obtained in $49 \%$ yield together with the reduced acyclic compounds $\underline{\mathbf{3 a}}$, $\underline{\mathbf{3}^{\prime} \mathbf{a}}$ in $51 \%(45: 55)$ yield (Table 2, entry 1). The influence of the water in the reaction selectivity was also investigated in $\mathrm{EtOH}: \mathrm{H}_{2} \mathrm{O}(9: 1)$ as the solvent. Thus, the electrolysis of $\underline{\mathbf{1 a}}$ afforded the cyclised product $\underline{\mathbf{2 a}}$ in 39 to $28 \%$ yield together with the acyclic products $\underline{\mathbf{3 a}}, \underline{\mathbf{3}^{\prime} \mathbf{a}}$ in $61(51: 49)$ to $42 \%(86: 14)$ yield (Table 2, entries 2 and 3). It can be observed that the presence of water did not strongly interfere with the overall cyclisation process and also with the selectivity of the reaction.

The same procedure was applied to the study of compound $\underline{\mathbf{1 c}}$ and it was seen that the electrolysis of $\underline{\mathbf{1 c}}$ gave the cyclised compounds $\underline{\mathbf{2 c}}, \underline{\mathbf{2}^{\prime} \mathbf{c}}$ in $99 \%$ yield (72:28) as the major 
products along with a minor amount of $\underline{\mathbf{3 c}}$ in a yield of $1 \%$ (Table 2 , entry 4 ). When the reaction was carried out under the same experimental conditions but in the presence of water, we observed that the overall cyclisation process and also the selectivity of the reaction were not strongly affected (Table 2, entries 5-7).

Comparing the results obtained with $\underline{\mathbf{1 a}}$ (entries 1-3) with those obtained for $\underline{\mathbf{1 c}}$ (entries 4-7), we can conclude that changing the substituents on the nitrogen position from methyl and allyl groups to two allyl groups had a significant effect on the yields and selectivities of the products. The same phenomenon was seen in the above results obtained in DMF (Table 1, entries 1 and 4). This is an entropy effect because by having two allyl groups on the nitrogen, the probability of cyclisation is increased (by a factor 2).

The electroreduction of $\underline{\mathbf{1 d}}$ was next explored in the presence of $[\mathrm{Ni}(\mathrm{tmc})] \mathrm{Br}_{2}$ using a sacrificial magnesium anode and a carbon fibre cathode in EtOH. It was found that the reduction of $\underline{\mathbf{1 d}}$ resulted in the formation of $\underline{\mathbf{2} \mathbf{d}}, \underline{\mathbf{2}} \mathbf{\mathbf { d }}$ in $98 \%$ yield (45:55), along with $\underline{\mathbf{3 d}}$ in $2 \%$ yield (Table 2, entry 8). In this case the reaction was also performed in EtOH: $\mathrm{H}_{2} \mathrm{O}$ (9:1) as the solvent, and it was seen that the water had little influence on the yields and on the selectivities of the reaction (Table 2, entries 9 and 10).

It should be noted that the diastereomeric (cis-to-trans) ratio for each $\underline{\mathbf{2} \mathbf{d}}$ and $\underline{\mathbf{2}} \mathbf{d}$ cyclic compounds stays around 78:22.

If now we compare the results obtained with $\underline{\mathbf{1 c}}$ (entries 4-6) with those obtained with 1d (entry 8-10), we can conclude that changing the substituent on the $\alpha$-amide position from hydrogen to methyl had little effect on the yields and on the product distribution of the reaction.

We also extended this study to chloro amide 1e. Thus, when the electroreduction of 1e was performed in the presence of $[\mathrm{Ni}(\mathrm{tmc})] \mathrm{Br}_{2}$ in $\mathrm{EtOH}$, using $\mathrm{Mg} / \mathrm{C}$ electrodes, the 
reaction proceeded to give the cyclic compounds $\underline{\mathbf{2 e}}, \underline{\mathbf{2}^{\prime} \mathbf{e}}$ in $58 \%$ to $62 \%$ yield along with the acyclic compounds $\underline{\mathbf{3 e}}, \underline{\mathbf{3}^{\prime} \mathbf{e}}$ in 32 to $35 \%$ yield (Table 2, entries 11 and 12). The influence of water was also studied and the reaction led to the cyclised products $\underline{\mathbf{2 e}}, \underline{\mathbf{2}^{\prime} \mathbf{e}}$ in $58(63: 37)$ to $46 \%$ (32:68) yield along with the acyclic compounds $\underline{\mathbf{3 e}}, \underline{\mathbf{3}^{\prime} \mathbf{e}}$ in 35 (48:52) to $24 \%$ (37:63) yield (Table 2, entries 13 and 14). From these results we can conclude that the presence of water does not interfere with the overall cyclisation process.

For cyclic compounds $\underline{\mathbf{2 e}}$ and $\underline{\mathbf{2}} \mathbf{e}$, the main cyclic diastereomer had the trans configuration in a ratio ranging from $80-100 \%$.

Hence, we can say that the nickel(II) complex, $[\mathrm{Ni}(\mathrm{tmc})] \mathrm{Br}_{2}$, used in $10-20$ mol \% showed an efficient catalytic activity for the electrochemical cleavage of carbon-halide bond of substrates $\underline{\mathbf{1}}$ in $\mathrm{EtOH}$ and $\mathrm{EtOH}-\mathrm{H}_{2} \mathrm{O}$ mixtures containing $0.006 \mathrm{M} \mathrm{TEABr}$.

In order to complete the results obtained by constant-current electrolysis, the electrochemical study of $N$-allyl- $\alpha$-haloamides $\underline{\mathbf{1}}$ in the presence of $\mathrm{Ni}(\mathrm{II})$ complexes in DMF, ACN, EtOH containing $0.1 \mathrm{M}$ of tetraalkylammonium salts as supporting electrolyte was performed by cyclic voltammetry.

Cyclic voltammograms of a $2 \mathrm{mM}[\mathrm{Ni}(\mathrm{tmc})] \mathrm{Br}_{2}$ solution in the absence and in the presence of $\underline{\mathbf{1 d}}$ at a vitreous carbon electrode in $\mathrm{DMF}$ containing $\mathrm{Bu}_{4} \mathrm{NBF}_{4}(0.1 \mathrm{M})$ are shown in Figure 1.

Haloamides $\underline{\mathbf{1 a}}-\underline{\mathbf{1 e}}$ alone were reduced at potentials below $-1.50 \mathrm{~V} v s \mathrm{Ag} / \mathrm{AgCl}$ under the same experimental conditions in DMF (Figure 1, curve A), ACN and EtOH (Figure 2, curve A) solvents.

In the absence of $\underline{\mathbf{1 d}}$, the cathodic peak potential for the reduction of $[\mathrm{Ni}(\mathrm{tmc})] \mathrm{Br}_{2}$ occurs at $-0.89 \mathrm{~V}$ and the corresponding anodic peak at a potential of $-0.82 \mathrm{~V}$, which corresponds respectively to the reduction of $[\mathrm{Ni}(\mathrm{tmc})]^{2+}$ to $[\mathrm{Ni}(\mathrm{tmc})]^{+}$and to the oxidation 
of $[\mathrm{Ni}(\mathrm{tmc})]^{+}$(Figure 1, curve B). Under these conditions, the ratio of the peak currents $\left(\mathrm{I}_{\mathrm{pa}}\right.$ $\left./ \mathrm{I}_{\mathrm{pc}}\right)$ is nearly unity. Formal electrode potential is $-0.86 \mathrm{~V} v s$ an $\mathrm{Ag} / \mathrm{AgCl} / 3 \mathrm{M} \mathrm{KCl}$ in water reference electrode. Therefore, from these results we can conclude that the reduction of the $[\mathrm{Ni}(\mathrm{tmc})] \mathrm{Br}_{2}$ complex is a one-electron reversible process, which is in agreement with the results obtained in previous investigations in DMF [15-19].

Formal electrode potentials for $[\mathrm{Ni}($ cyclam $)] \mathrm{Br}_{2}$ and $[\mathrm{Ni}(\mathrm{CR})] \mathrm{Cl}_{2}$ in $\mathrm{DMF}$ solutions are -1.36 and $-0.56 \mathrm{~V} v s \mathrm{Ag} / \mathrm{AgCl} / 3 \mathrm{M} \mathrm{KCl}$ in water reference electrode, respectively.

Upon addition of different concentrations of $\underline{\mathbf{1 d}}$ to the $[\mathrm{Ni}(\mathrm{tmc})]^{2+}$ solution, its voltammetric behaviour changed (Figure 1, curves C-D). It is was observed that upon addition of low concentrations of $\underline{\mathbf{1 d}}$ the reduction process for $\mathrm{Ni}(\mathrm{II})$ complex became completely irreversible and the reduction peak increased in height. On further addition of

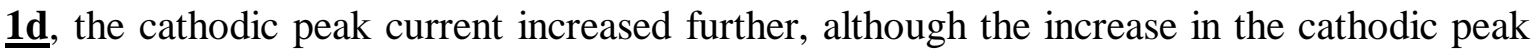
current was not proportional to the concentration of unsaturated halide over the whole range. These results suggest that, on the time-scale of cyclic voltammetry, the reaction between the bromoamide and the electrogenerated $\mathrm{Ni}(\mathrm{I})$ species is always fast (the anodic peak for the oxidation of $\mathrm{Ni}(\mathrm{I})$ to $\mathrm{Ni}(\mathrm{II})$ complexes is absent) but the regeneration of the $\mathrm{Ni}$ (II) species by the chemical sequence is a slow process (the increase in peak current for the $\mathrm{Ni}(\mathrm{II})$ complex reduction is a measure of the rate at which the complex is regenerated). The data from these experiments are presented in Table 3. Similar results were found in the presence of the other substrates $\underline{\mathbf{1}}$.

Furthermore, we have performed the cyclic voltammetric study of $[\mathrm{Ni}(\mathrm{tmc})] \mathrm{Br}_{2}$ in the absence and in the presence of $\underline{\mathbf{1 d}}$ in $\mathrm{EtOH}$ containing $\mathrm{Et}_{4} \mathrm{NBr}(0.1 \mathrm{M})$ as supporting electrolyte. Thus, Figure 2 shows cyclic voltammograms recorded on vitreous carbon electrode for the reduction of $[\mathrm{Ni}(\mathrm{tmc})] \mathrm{Br}_{2}$ in $\mathrm{EtOH}$ in the absence (curve $\mathrm{B}$ ) and in the 
presence of different concentrations of bromoamide $\underline{\mathbf{1 d}}$ (curves C-D). It can be observed the cathodic peak potential $\left(\mathrm{E}_{\mathrm{pc}}\right)$ for the reduction of $[\mathrm{Ni}(\mathrm{tmc})]^{2+}$ to $[\mathrm{Ni}(\mathrm{tmc})]^{+}$appeared at $-0.91 \mathrm{~V}$ and the anodic peak potential $\left(\mathrm{E}_{\mathrm{pa}}\right)$ at $-0.80 \mathrm{~V}$. The ratio of the peak currents $\left(\mathrm{I}_{\mathrm{pa}} / \mathrm{I}_{\mathrm{pc}}\right)$ was close to unity. Formal electrode potential is $-0.86 \mathrm{~V} v \mathrm{Ag} / \mathrm{AgCl} / 3 \mathrm{M} \mathrm{KCl}$ in water reference electode. From these observations we can also conclude that the reduction of $[\mathrm{Ni}(\mathrm{tmc})] \mathrm{Br}_{2}$ complex is a one-electron reversible process. These results are in agreement with the results of previous investigations carried out in $\mathrm{EtOH}$ as the solvent [29]. The experiments of cyclic voltammetry for the reduction of $[\mathrm{Ni}(\mathrm{tmc})] \mathrm{Br}_{2}$ in the presence of substrates $\underline{\mathbf{1 d}}$ (Figure 2, curves C-D) indicated that the addition of the bromoamide compound to the $\mathrm{Ni}$ (II) solution resulted in an important increase of the reduction peak intensity at the reduction potential of the mediator, as well as in the disappearance of the anodic wave, as a result of the catalyst-substrate reaction. A positive shift in the cathodic peak potential with an increase in the cathodic peak current for the reduction of $[\mathrm{Ni}(\mathrm{tmc})]^{2+}$ was observed, as it was recycled catalytically. The data obtained from these experiments are presented in Table 3. All these same trends were also observed for substrates $\underline{\mathbf{1 a}}, \underline{\mathbf{1 c}}$ and $\underline{\mathbf{1 e}}$. Comparing the data presented in Table 3 (entries 1 and 2) led us to conclude that the reduction of $\underline{\mathbf{1}}$ by the electrogenerated nickel(I) complex in EtOH is a faster catalytic process than in DMF. This is seen by the large cathodic peaks on cyclic voltammograms for solutions containing $[\mathrm{Ni}(\mathrm{tmc})]^{2+}$ and an excess of substrate (the increase in peak current for the $\mathrm{Ni}$ (II) complex reduction is a measure of the rate at which the complex is regenerated and hence that the complete catalytic cycle is rapid). It leads to the possibility of quick and efficiently synthetic electrolyses with only a catalytic amount of the nickel(II) complex. 
Without suggesting intimate mechanistic details, on the basis of the above-described results, we propose the following reaction mechanism (Scheme 1).

After the reversible one-electron reduction of $[\mathrm{Ni}(\mathrm{tmc})]^{2+}$, the resulting $[\mathrm{Ni}(\mathrm{tmc})]^{+}$ transfers one electron to $\underline{\mathbf{1}}$, cleaving the carbon-bromine bond homolytically, to give the radical intermediate $\underline{4}$ [reaction (2) and reaction (3)]. According to Halcrow and coworkers [30], who have presented an extensive review of the catalytic reactions involving nickel(II) complexes and alkyl halides, this is a radical reaction, generating $\mathrm{R} \bullet$ transients and / or Ni-alkyls, which then decay to form alkanes, alkenes and dimeric or cyclic organics: the identity and distribution of the observed products varies dramatically with organic substrates and nickel catalysts, and with the substrate/catalyst ratio employed. Indeed, it is generally considered [30] that $\mathrm{Ni}^{\mathrm{I}} \mathrm{L}^{+}$complexes transfer one electron to alkyl halides via an inner-sphere mechanism, whereas $\mathrm{Ni}^{\mathrm{I}} \mathrm{L}^{-}$complexes undergo a $\mathrm{SN}_{2}$-type nucleophilic substitution at alkyl halides. In both cases an alkyl-nickel intermediate may be formed whose further evolution may generate alkyl radicals. Furthermore, according to detailed mechanistic studies by Bakac et al. [31-39] on the electroreduction of alkyl halides by $[\mathrm{Ni}(\mathrm{tmc})]^{+}$in aqueous media, reactions (2) and (3) are likely to be the rate-determining steps. Once produced, $\underline{\mathbf{4}}$ undergoes rapid intramolecular cyclisation to give the carbocyclic radicals $\underline{\mathbf{5}}$ and/ or it can undergo a reductive protonation to afford the acyclic compound $\underline{\mathbf{3}}$. The carbocyclic radicals $\underline{\mathbf{5}}$, after abstraction of a hydrogen atom from the medium, afford $\underline{\mathbf{2}}$ $(\operatorname{reaction}(2))$.

The formation of $\underline{\mathbf{2}^{\prime}}$ and $\underline{\mathbf{3}^{\prime}}$, arises from the remaining double bond reduction under the electrolysis conditions. To probe further the electroreduction of the allyl function, we carried out an electrochemical experiment in which a constant-current electrolysis of a 
solution of EtOH: $\mathrm{H}_{2} \mathrm{O}(9: 1)$ containing $0.006 \mathrm{M}$ TEABr and $15 \mathrm{mM} \underline{\mathbf{2 c}}$ was performed. During the electrolysis the reaction was followed taking samples at different times and analysing them by GC until complete consumption of the starting material. Interestingly, we found that at $\mathrm{F}=1 / \mathrm{mol}$ we had $100 \%$ of the original $\underline{\mathbf{2 c}}$; at $\mathrm{F}=2 / \mathrm{mol}, 4 \%$ of the $\underline{\mathbf{2 c}}$ was converted into $\underline{\mathbf{2}^{\prime} \mathbf{c}}$; at $\mathrm{F}=4 / \mathrm{mol}, 50 \%$ of $\underline{\mathbf{2 c}}$ was converted to $\underline{\mathbf{2}^{\prime} \mathbf{c}}$; and finally after $\mathrm{F}=$ $22 / \mathrm{mol}, 86 \%$ of $\underline{\mathbf{2}^{\prime} \mathbf{c}}$ was formed. On the basis of the latter experiments, we conclude that the conversion of $\underline{\mathbf{2}}$ to $\underline{\mathbf{2}^{\prime}}$ and of $\underline{\mathbf{3}}$ to $\underline{\mathbf{3}^{\prime}}$ occurs slowly as a side-reaction during the electrolysis due to the electroreduction of the free allyl function in $\underline{\mathbf{2}}$ and in $\underline{\mathbf{3}}$.

\section{Conclusions}

The results of the cyclisation of $\underline{\mathbf{1}}$ in $\mathrm{EtOH}$ are in agreement with related results reported by Medeiros et al.[40] in EtOH, where the intramolecular cyclisation of bromo propargyloxy esters and bromo allyloxy esters led to the corresponding cyclic ethers.

Briefly comparing the reduction of $\underline{\mathbf{1}}$ catalysed by $[\mathrm{Ni}(\mathrm{tmc})] \mathrm{Br}_{2}$ in protic media $\left(\mathrm{EtOH}, \mathrm{EtOH}-\mathrm{H}_{2} \mathrm{O}\right)$ with the electrochemical studies in DMF it can be concluded that the yields and selectivities obtained in protic solvents are much better than those obtained in DMF, in particular for substrates $\underline{\mathbf{1 c}}-\underline{\mathbf{1 e}}$.

In summary, we have found that the electrochemical radical-type cyclisation of haloamides $\underline{\mathbf{1}}$ in solvents such as $\mathrm{EtOH}$ or $\mathrm{EtOH}-\mathrm{H}_{2} \mathrm{O}$ led to the corresponding lactams in good yields. Moreover, this investigation provides an example of the feasibility of preparative-scale organic electrosynthesis in "green" solvents in a catalytic and environmentally friendly procedure at ambient temperature. 


\section{Acknowledgements}

Most of this research was conducted while M.J.M. was a Visiting Scholar at University of Nice. In addition, we are grateful to Fundação para a Ciência e Tecnologia (PPCDT/QUI/55576/2004) for financial support of this work.

\section{REFERENCES}

[1] B. Giese, B. Kopping, T. Gobel, J. Dickhaut, G. Thoma, F. Trach, Org. React. 48 (1996) 301 (and references therein).

[2] B. Giese, Radicals in Organic Synthesis, Formation of Carbon-Carbon Bonds, Pergamon, Oxford, 1986.

[3] J. Fossey, D. Lefort, J. Sorba, Free Radicals in Organic Chemistry, Wiley, New York, 1995.

[4] V. Teetz, R.Geiger, H. Gaul, Tetrahedron Lett. 25 (1984) 4479.

[5] V. Teetz, H. Gaul, Tetrahedron Lett. 25 (1984) 4483 (and references cired therein).

[6] J.M. Clough, G. Pattenden, P.G. Wight, Tetrahedron Lett. 30 (1989) 7469.

[7] T. Sato, Y. Wada, M. Nishimoto, H. Ishibashi, M. Ikeda, J. Chem. Soc., Perkin Trans.1 (1989) 879.

[8] H. Ishibashi, T.S. So, K. Okochi, T. Sato, N. Nakamura, H. Nakatani, M. Ikeda, J. Org. Chem. 56 (1991) 95.

[9] A.J. Clark, P. Wilson, Tetrahedron Lett. 49 (2008) 4848.

[10] S. Ozaki, E. Matsui, J. Waku, H. Ohmori, Tetrahedron Lett. 38 (1997) 2705 (and references cited therein).

[11] A. P. Esteves, A. M. Freitas, M. J. Medeiros, D. Pletcher, J. Electroanal. Chem. 499 (2001) 95 . 
[12] E. Duñach, A. P. Esteves, A. M. Freitas, M. J. Medeiros, S. Olivero, Tetrahedron Lett. 40 (1999) 8693.

[13] M. Ihara, A. Katsumata, F. Setsu, Y. Tokunaga, K. Fukumoto, J. Org. Chem. 61 (1996) 677.

[14] S. Olivero, J. -P. Rolland, E. Duñach, Organometallics 17 (1998) 3747 (and references cited therein).

[15] E. Duñach, A. P. Esteves, A. M. Freitas, M. A. Lemos, M. J. Medeiros, S. Olivero, Pure Appl. Chem. 73 (2001) 1941.

[16] A. P. Esteves, D. M. Goken, J. L. Klein, M. A. Lemos, M. J. Medeiros, D. G. Peters, J. Org. Chem. 68 (2003) 1024.

[17] E. Duñach, A. P. Esteves, M. J. Medeiros, S. Olivero, Tetrahedron Lett. 45 (2004) 7935.

[18] A.P. Esteves, D.M. Goken, L.J. Klein, M.J. Medeiros, D.G. Peters, Eur. J. Org. Chem. (2005) 4852.

[19] A.P. Esteves, E.C. Ferreira, M. J. Medeiros, Tetrahedron 63 (2007) 2006.

[20] S. Oazaki, H. Matsushita, H. Ohmori, J. Chem. Soc., Perkin Trans. 1 (1993) 2339.

[21] S. Oazaki, H. Matsushita, M. Emoto, H. Ohmori, Chem. Pharm. Bull. 43 (1995) 32.

[22] B. Bosnich, M.L. Tobe, G.A. Webb, Inorg. Chem. 4 (1965) 1109.

[23] J.L. Karn. D.H. Busch, Inorg. Chem. 8 (1969) 1149.

[24] R. McCague, R. G. Pritchard, R. J. Stoodley, D. S. Williamson, Chem. Commun. (1998) 2691.

[25] J. Chaussard, J.C. Folest, J.Y. Nédèlec, J. Périchon, S. Sibille, M. Troupel, Synthesis (1990) 369.

[26] K. L Vieira, D. G. Peters, J. Electroanal. Chem. 196 (1985) 93.

[27] G. Long, M. E. Meek, J. Environ. Sci. Heal. C19 (2001) 161. 
[28] J. H. Sohn, M. J. Han, M. Y. Lee, S. - K. Kang, J. S. Yang, J. Pharmaceut. Biomed. 37 (2005) 165.

[29] E. Duñach, A. P. Esteves, M. J. Medeiros, S. Olivero, Green Chemistry 8 (2006) 380.

[30] M.A. Halcrow and G. Christou, Chem. Rev. 94 (1994) 2421.

[31] A. Bakac, J.H. Espenson, J. Am. Chem. Soc. 108 (1986) 713.

[32] A. Bakac, J.H. Espenson, J. Am. Chem. Soc. 108 (1986) 719.

[33] A. Bakac, J.H. Espenson, J. Am. Chem. Soc. 108 (1986) 5353.

[34] M.S. Ram, A. Bakac, J.H. Espenson, Inorg. Chem. 25 (1986) 3267.

[35] M.S. Ram, J.H. Espenson, A. Bakac, Inorg. Chem. 25 (1986) 4115.

[36] J.H. Espenson, M.S. Ram, A. Bakac, J. Am. Chem. Soc. 109 (1987) 6892.

[37] M.S. Ram, A. Bakac, J.H. Espenson, Inorg. Chem. 27 (1988) 2011.

[38] M.S. Ram, A. Bakac, J.H. Espenson, Inorg. Chem. 27 (1988) 4231.

[39] N. Sadler, S.L. Scott, A. Bakac, J.H. Espenson, M.S. Ram, Inorg. Chem. 28 (1989) 3951.

[40] E. Duñach, M. J. Medeiros, Electrochimica Acta 53 (2008) 4477. 


\section{CAPTION FOR FIGURES}

Figure 1. Cyclic voltammograms recorded with a glassy carbon electrode (area $=0.07 \mathrm{~cm}^{2}$ ) at $100 \mathrm{mV} \mathrm{s}^{-1}$ in DMF containing $0.10 \mathrm{M} \mathrm{TBABF}_{4}$ : (A) $2 \mathrm{mM} \underline{\mathbf{1 d}}$; (B) $2 \mathrm{mM}[\mathrm{Ni}(\mathrm{tmc})] \mathrm{Br}_{2}$; (C) $2 \mathrm{mM}[\mathrm{Ni}(\mathrm{tmc})] \mathrm{Br}_{2}$ and $10 \mathrm{mM} \underline{\mathbf{1 d}}$; (D) $2 \mathrm{mM}[\mathrm{Ni}(\mathrm{tmc})] \mathrm{Br}_{2}$ and $20 \mathrm{mM} \underline{\mathbf{1 d}}$.

Figure 2. Cyclic voltammograms recorded with a glassy carbon electrode $\left(\right.$ area $\left.=0.07 \mathrm{~cm}^{2}\right)$ at $100 \mathrm{mV} \mathrm{s}^{-1}$ in EtOH containing $0.10 \mathrm{M} \mathrm{TEABr}$ : (A) $2 \mathrm{mM} \underline{\mathbf{1 d}}$; (B) $1 \mathrm{mM}[\mathrm{Ni}(\mathrm{tmc})] \mathrm{Br}_{2}$; (C) $1 \mathrm{mM}[\mathrm{Ni}(\mathrm{tmc})] \mathrm{Br}_{2}$ and $10 \mathrm{mM} \underline{\mathbf{1 d}}$; (D) $1 \mathrm{mM}[\mathrm{Ni}(\mathrm{tmc})] \mathrm{Br}_{2}$ and $10 \mathrm{mM} \underline{\mathbf{1 d}}$. 


\begin{tabular}{|c|c|c|c|c|c|}
\hline Entry & Substrate & Solvent & Catalyst & $\begin{array}{c}\text { Cyclised } \\
\text { Products } \\
\text { (2:2' ratio) }\end{array}$ & $\begin{array}{c}\text { Yield of } \\
\text { cyclised } \\
\text { products } \\
(\%)\end{array}$ \\
\hline 1 & $\underline{1 \mathbf{a}}$ & DMF & {$[\mathrm{Ni}(\mathrm{tmc})] \mathrm{Br}_{2}$} & $\underline{2 \mathbf{a}}$ & 18 \\
\hline $2^{a}$ & $\underline{1 a}$ & DMF & {$[\mathrm{Ni}(\mathrm{tmc})] \mathrm{Br}_{2}$} & $\underline{\mathbf{2 a}}$ & 14 \\
\hline $3^{\mathrm{b}}$ & $\underline{1 b}$ & $\mathrm{CH}_{3} \mathrm{CN}$ & {$[\mathrm{Ni}($ cyclam $)] \mathrm{Br}_{2}$} & $\underline{2 \mathbf{b}}$ & $<5$ \\
\hline 4 & $\underline{1 c}$ & DMF & {$[\mathrm{Ni}(\mathrm{tmc})] \mathrm{Br}_{2}$} & $\frac{\mathbf{2 c}}{(79}, \frac{\mathbf{2}^{\prime} \mathbf{c}}{21)}$ & 66 \\
\hline $5^{\mathrm{c}}$ & $\underline{1 c}$ & $\mathrm{CH}_{3} \mathrm{CN}$ & {$[\mathrm{Ni}(\mathrm{tmc})] \mathrm{Br}_{2}$} & $\frac{\mathbf{2 c}}{(94: 6)}$ & 53 \\
\hline 6 & $\underline{1 c}$ & DMF & {$[\mathrm{Ni}($ cyclam $)] \mathrm{Br}_{2}$} & $\frac{\mathbf{2 c}}{(78: 22)}$ & 49 \\
\hline 7 & $\underline{1 c}$ & DMF & {$[\mathrm{Ni}(\mathrm{CR})] \mathrm{Br}_{2}$} & $\frac{\mathbf{2 c},}{(59: 41)}$ & 32 \\
\hline $8^{\mathrm{b}}$ & $\underline{1 d}$ & $\mathrm{CH}_{3} \mathrm{CN}$ & {$[\mathrm{Ni}($ cyclam $)] \mathrm{Br}_{2}$} & $\underline{\mathbf{2}}^{\mathrm{d}}$ & 27 \\
\hline 9 & $1 \mathrm{e}$ & $\mathrm{CH}_{3} \mathrm{CN}$ & {$[\mathrm{Ni}($ cyclam $)] \mathrm{Br}_{2}$} & $\underline{\mathbf{2 e}}^{\mathrm{d}}$ & 22 \\
\hline
\end{tabular}

a) In the presence of $\mathrm{NH}_{4} \mathrm{Cl} 30 \mathrm{mM}$. ${ }^{\text {b) }}[\mathrm{RBr}] /\left[\mathrm{Ni}(\mathrm{II})=10\right.$; ${ }^{\mathrm{c})}$ Using an aluminium anode. ${ }^{\text {d) }}$ Diastereomeric (cis-to-trans) ratio of $\underline{\mathbf{2 d}}$ and $\underline{\mathbf{2 e}}$ was not determined (see Table 2). 
Table 2. Electrochemical intramolecular cyclisation of allyl haloamides $\underline{1}$ (15 mM) catalysed by $[\mathrm{Ni}(\mathrm{tmc})] \mathrm{Br}_{2}$ complex $(20 \mathrm{~mol} \%)$ at a carbon fiber cathode using a Mg anode in EtOH containing $\mathrm{Et}_{4} \mathrm{NBr}(6 \mathrm{mM})$ at $\mathbf{j}=0.15 \mathrm{~A} \mathrm{dm}^{-2}$

\begin{tabular}{|c|c|c|c|c|}
\hline Entry & Substrate & Solvent & $\begin{array}{c}\text { Cyclised } \\
\text { Products } \\
\left(2: 2^{\prime} \text { ratio) }\right.\end{array}$ & $\begin{array}{c}\text { Yield of } \\
\text { cyclized } \\
\text { products }(\%)\end{array}$ \\
\hline 1 & $\underline{1 \mathbf{a}}$ & $\mathrm{EtOH}$ & $\underline{2 \mathbf{a}}$ & 49 \\
\hline 2 & $\underline{1 \mathbf{a}}$ & EtOH: $\mathrm{H}_{2} \mathrm{O}(9: 1)$ & $\underline{\mathbf{2 a}}$ & 39 \\
\hline $3^{\mathrm{a}}$ & $\underline{1 \mathbf{a}}$ & $\mathrm{EtOH}: \mathrm{H}_{2} \mathrm{O}(9: 1)$ & $\underline{2 a}$ & 28 \\
\hline 4 & $\underline{1 c}$ & $\mathrm{EtOH}$ & $\frac{\mathbf{2 c}}{\left(72: \frac{\mathbf{2}^{\prime} \mathbf{c}}{28)}\right.}$ & 99 \\
\hline 5 & $\underline{1 c}$ & EtOH: $\mathrm{H}_{2} \mathrm{O}(9: 1)$ & $\frac{\mathbf{2 c},}{(75: 25)}$ & 97 \\
\hline $6^{\mathrm{a}}$ & $\underline{1 c}$ & $\mathrm{EtOH}: \mathrm{H}_{2} \mathrm{O}(9: 1)$ & $\frac{\mathbf{2 c}}{(71: 29)}$ & 97 \\
\hline $7^{\mathrm{b}}$ & $\underline{1 c}$ & EtOH: $\mathrm{H}_{2} \mathrm{O}(9: 1)$ & $\frac{\mathbf{2 c}}{\left(81: \frac{\mathbf{2}}{19} \mathbf{c}\right.}$ & 78 \\
\hline 8 & $\underline{1 d}$ & $\mathrm{EtOH}$ & $\frac{\mathbf{2 d}}{(45: 55)}, \frac{\mathbf{2} \mathbf{d}}{55}$ & 98 \\
\hline 9 & $\underline{1 \mathrm{~d}}$ & EtOH: $\mathrm{H}_{2} \mathrm{O}(9: 1)$ & $\frac{\mathbf{2 d}}{\left(78: \frac{2}{2} \mathbf{d}\right.}$ & 94 \\
\hline $10^{\mathrm{a}}$ & $\underline{1 \mathrm{~d}}$ & $\mathrm{EtOH}: \mathrm{H}_{2} \mathrm{O}(9: 1)$ & $\frac{\mathbf{2 d}}{(64: 36)}, \frac{\mathbf{2} \mathbf{d}}{36)}$ & 97 \\
\hline 11 & $\underline{1 \mathrm{e}}$ & $\mathrm{EtOH}$ & $\frac{\mathbf{2 e},}{(33: 67)}$ & 58 \\
\hline $12^{\mathrm{a}}$ & $\underline{1 \mathrm{e}}$ & $\mathrm{EtOH}$ & $\frac{\mathbf{2} \mathbf{e}_{\mathbf{2}}}{\left(40: \frac{\mathbf{2}}{\mathbf{e}}\right.}$ & 62 \\
\hline 13 & $\underline{1 \mathrm{e}}$ & $\mathrm{EtOH}: \mathrm{H}_{2} \mathrm{O}(9: 1)$ & $\frac{\mathbf{2 e}}{(63: 37)}, \frac{\mathbf{2} \mathbf{e}}{37}$ & 58 \\
\hline $14^{\mathrm{a}}$ & $\underline{1 \mathrm{e}}$ & EtOH: $\mathrm{H}_{2} \mathrm{O}(9: 1)$ & $\underline{\mathbf{2 e}}, \frac{\mathbf{2}^{\prime} \mathbf{e}}{(32: 68)}$ & 46 \\
\hline
\end{tabular}


Table 3 - Data of the ratio $I_{c} / I_{d}$ obtained from the cyclic voltammetry experiments of $[\mathrm{Ni}(\mathrm{tmc})]^{2+}$ in the presence of different concentrations of $\underline{1 \mathrm{~d}}$ in different media. Potential scan rate $0.10 \mathrm{~V} / \mathrm{s}$.

\begin{tabular}{ccccc}
\hline \multirow{2}{*}{ Medium } & {$[\mathbf{N i}(\mathbf{I I})] / \mathbf{m M}$} & \multicolumn{3}{c}{$\mathbf{I}_{\mathbf{c}} / \mathbf{I}_{\mathbf{d}}{ }^{\mathrm{a}}$} \\
\cline { 3 - 5 } & 2 & 1.3 & $\gamma=5^{\mathrm{b}}$ & $\gamma=10^{\mathrm{b}}$ \\
\hline $\mathrm{DMF} / 0.10 \mathrm{M} \mathrm{TEABF}_{4}$ & 1 & 3.1 & 6.5 & 5.6 \\
$\mathrm{EtOH} / 0.10 \mathrm{M} \mathrm{TEABr}$ & 1 & 6.6 & 10.7 \\
\hline
\end{tabular}

${ }^{a} I_{c}$ - catalytic peak current intensity of the catalyst in the presence of substrate and $I_{d}$ - peak current intensity of the catalyst in the absence of substrate; ${ }^{\mathrm{b}} \gamma \square=[\mathrm{RBr}] /[\mathrm{Ni}$ (II)]. 


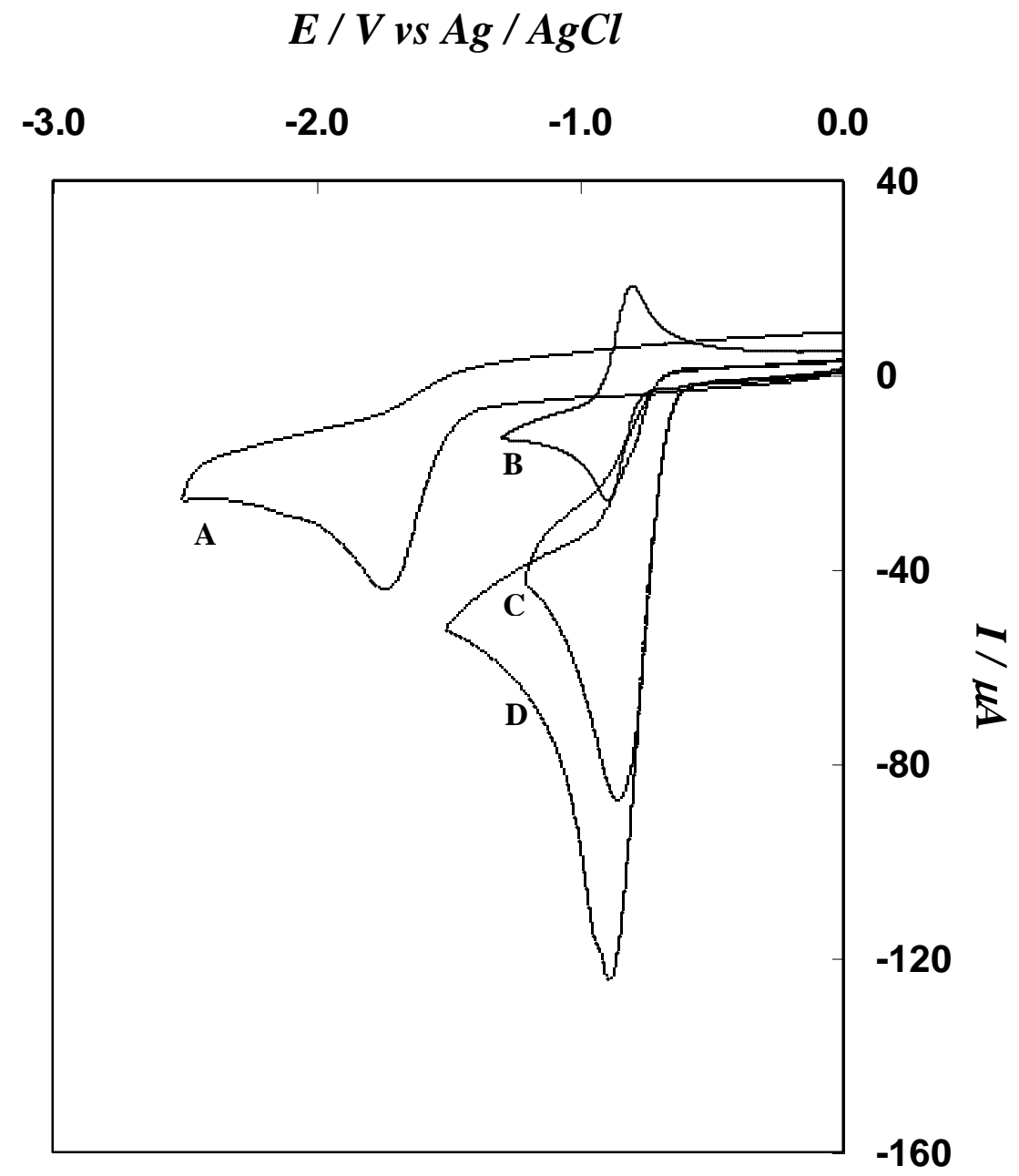

Figure 1 


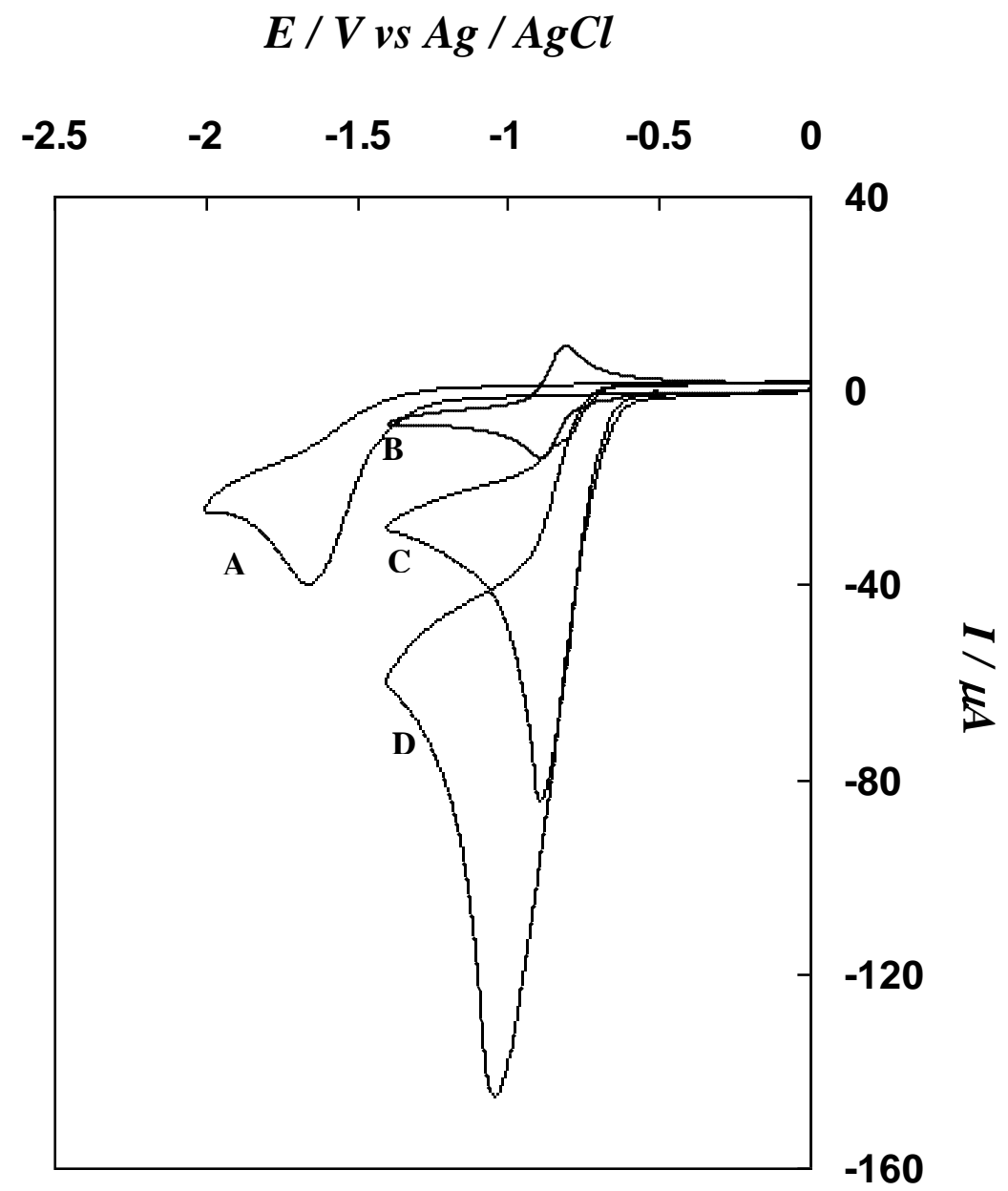

Figure 2 
$[\mathrm{Ni}(\mathrm{tmc})]^{2+}+\mathrm{e}^{-} \Longrightarrow[\mathrm{Ni}(\mathrm{tmc})]^{+}$

$\left[\mathrm{Ni(tmc)]^{+ }}\right.$

1a: $\mathrm{R}_{1}=\mathrm{H} ; \mathrm{R}_{2}=\mathrm{CH}_{3} ; \mathrm{X}=\mathrm{Br}$

1d: $\mathrm{R}_{1}=\mathrm{CH}_{3} ; \mathrm{R}_{2}=$ allyl; $\mathrm{X}=\mathrm{Br}$

1b: $\mathrm{R}_{1}=\mathrm{CH}_{3} ; \mathrm{R}_{2}=\mathrm{CH}_{3} ; \mathrm{X}=\mathrm{Br}$

1c: $\mathrm{R}_{1}=\mathrm{H} ; \mathrm{R}_{2}=$ allyl; $\mathrm{X}=\mathrm{Br}$ 1e: $\mathrm{R}_{1}=$ phenyl; $\mathrm{R}_{2}=$ allyl; $\mathrm{X}=\mathrm{Cl}$

Scheme 1 